Utah State University

DigitalCommons@USU

$10-15-2012$

\title{
Influence of Aboveground Vegetation on Seed Bank Composition and Distribution in a Great Basin Desert Sagebrush Community
}

Kristen M. Pekas

Utah State University, kristen.pekas@idfg.idaho.gov

Eugene W. Schupp

Utah State University, eugene.schupp@usu.edu

Follow this and additional works at: https://digitalcommons.usu.edu/sagestep_articles

Part of the Life Sciences Commons

\section{Recommended Citation}

Pekas, K., and E.W. Schupp. 2013. Influence of aboveground vegetation on seed bank composition and distribution in a Great Basin sagebrush community. Journal of Arid Environments, 88: 113-120.

This Article is brought to you for free and open access by the Publications at DigitalCommons@USU. It has been accepted for inclusion in Articles by an authorized administrator of DigitalCommons@USU. For more information, please contact digitalcommons@usu.edu.

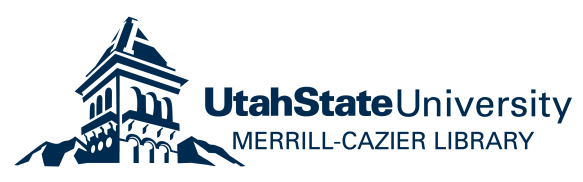


1 Influence of aboveground vegetation on seed bank composition and distribution in a

2 Great Basin Desert sagebrush community

4 Kristen M. Pekas ${ }^{a, b}$, Eugene W. Schupp ${ }^{a}$

5 a Department of Wildland Resources and the Ecology Center, 5230 Old Main Hill, Utah State

6 University, Logan, UT 84322-5230

7 bPresent address: Idaho Natural Heritage Program, Idaho Department of Fish and Game, 3316

$8 \quad 16^{\text {th }}$ St., Lewiston, ID 83501

9

10 e-mail Kristen M. Pekas: kristen.pekas@idfg.idaho.gov

11 e-mail Eugene W. Schupp: eugene.schupp@usu.edu

12

13 Correspondence:

$14 \quad$ Kristen Pekas

15 tel: 678-983-3340, fax: 208-799-5012, address: $331616^{\text {th }}$ St., Lewiston, ID 83501 


\section{Abstract}

The quantity, composition, and spatial dispersion of seed banks can greatly affect community dynamics. While seed banks of hot deserts have been studied extensively, little is known about seed banks in cold deserts, in particular the relationship between the seed bank and the aboveground vegetation. We investigated the relationship between the seed bank and aboveground vegetation and the effect of microhabitat (shrub interspace or beneath shrub) and aboveground community phase (high or low perennial bunchgrass cover) on the seed bank of a Great Basin Desert sagebrush community. The seed bank and aboveground vegetation differed in their most dominant species, resulting in moderately dissimilar species compositions as determined by Sørensen's similarity index and Bray-Curtis distance. In contrast, comparing the seed bank species composition to the aboveground vegetation structure (functional groups) using non-metric multidimensional scaling (NMDS) revealed a correspondence between the two communities. Shrub seed densities were higher beneath shrubs. Neither microhabitat nor community phase explained variation in total seed density or species richness. Therefore, our measures of the aboveground vegetation did not influence seed density across functional groups or species richness, and the similarity between the seed bank and aboveground vegetation varied depending on the aboveground organizational level used in comparisons.

Key words: seed bank, aboveground vegetation, shrub, Great Basin Desert, similarity, microhabitat

\section{Introduction}

The majority of Great Basin Desert species rely on seeds for propagation; however, seed banks (or seed pools)of this desert are poorly understood (Kemp, 1989). Seed banks may help 
41 re-establish species that have become locally extinct aboveground. Evaluations of North

42 American desert seed banks suggest that those of the Great Basin Desert consist of fewer annual

43 and more perennial species than do hot desert seed banks (Kemp, 1989; Guo et al., 1999).

44 Although maximum seed densities are generally similar among the North American deserts,

45 there are some areas of the Great Basin Desert that appear to have very small seed banks (Hassan

46 and West, 1986).

$47 \quad$ Annual species are more likely than perennial species to form persistent seed banks

48 because they tend to produce dormant seeds (Jurado and Flores, 2005). This strategy allows

49 seeds to wait for proper germination cues which may increase the chance of establishment and

50 survival. However, a long-term seed banking strategy may be difficult for annuals to achieve

51 because of seed reductions caused by continuous germination and granivory (Kigel, 1995). Due

52 to the nature of perennial species, seeds are less likely to be dormant, and therefore, seed banks

53 tend to be transient. Species that form transient seed banks are at risk of becoming locally

54 extinct, especially if seed production is limited (O’Connor, 1991). Seed production can be

55 limited by a number of factors, such as invasive species which may cause native perennial

56 species to produce fewer seeds and die prematurely if the density of the invader is high (Vilà and

57 Gimeno, 2007) or by drought years that limit flowering and seed production (St. Clair et al., 58 2009).

The invasion of Bromus tectorum (cheatgrass) has altered the structure and composition

60 of Great Basin Desert seed banks. Studies examining seed banks of degraded sagebrush

61 communities have shown shifts to greater annual seed abundance with cheatgrass invasion

62 (Young and Evans, 1975; Humphrey and Schupp, 2001). Even in systems that are not

63 considered to be dominated by cheatgrass, introduced species can still account for 20 percent of 
64 the total number of seeds in the seed bank (Guo et al., 1999).

65 The relationship between the seed bank and aboveground vegetation is not well

66 understood in Great Basin Desert sagebrush communities. Plant communities dominated by

67 perennial species usually have relatively low aboveground-belowground similarities, while

68 annual-dominated communities tend to have a greater correspondence between aboveground

69 vegetation and the seed bank (Thompson and Grime, 1979; Ungar and Woodell, 1993; Milberg,

70 1995; Bakker et al., 1996; Osem et al., 2006), at least partly because annual-dominated

71 communities arise yearly from the available seed bank, which reflects vegetation of the previous

72 year (Osem et al., 2006).

73 When comparing the relationship between the seed bank and aboveground vegetation

74 among forest, grassland (including desert), and wetland seed banks, grassland standing

75 vegetation is most similar to the seed banks in terms of species composition (Hopfensperger,

76 2007). In desert grasslands, extreme environmental conditions may select for species that rely on

77 persistent seed banks, resulting in similar above and belowground communities (Henderson et

78 al., 1988). However, higher similarity between the seed bank and aboveground vegetation in

79 desert grasslands is more likely due to limited dispersal and aggregated seed patterns

80 surrounding parent plants (Shaukat and Siddiqui, 2004). In contrast, some studies have found a

81 lack of correspondence between the seed bank and aboveground vegetation in grasslands which

82 has been attributed to different dominant species in the aboveground and seed bank communities

83 (Eriksson and Eriksson, 1997; Kalamees and Zobel, 1997). For example, the most dominant

84 species in the seed bank may be overrepresented due to high production of small seeds (Eriksson 85 and Eriksson, 1997).

86 The aboveground vegetation not only influences the community composition of the seed 
87 bank but also the distribution of the seeds. Although the distribution of seeds within desert seed

88 banks is spatially variable, seeds are frequently more abundant under shrub and tree canopies

89 than in interspaces (Nelson and Chew, 1977; Guo et al., 1998; Marone et al., 2004) and exhibit

90 an aggregated seed pattern due to seeds settling close to the mother plant (Shaukat and Siddiqui,

91 2004). A study investigating spatial patterns of species richness found higher species richness at

92 the mid-point and furthest sampling point from shrubs (2 $\mathrm{m}$ and $6 \mathrm{~m}$ from shrubs ; $\mathrm{Li}, 2008)$. In

93 pinyon-juniper woodlands, seed densities and species richness were highest in interspaces and

94 the interface between interspaces and litter under trees (Koniak and Everett, 1983). Shrubs and

95 trees affect the spatial distribution of seeds as they can act as a barrier, altering wind dynamics

96 and subsequent seed deposition patterns. (Guo et al., 1998; Li, 2008; Li et al., 2009). Seeds

97 often accumulate beneath shrubs because they decrease wind velocity and physically trap seeds,

98 leading to deposition close to shrubs (Bullock and Moy, 2004). Seeds can also be redistributed

99 from interspaces to litter beneath shrubs by wind and water (phase II dispersal; Chambers and

100 MacMahon, 1994).

101 This study explores the seed bank and the aboveground vegetation within a Great Basin

102 Desert plant community and how the aboveground vegetation influences the seed bank

103 community composition and seed distributions. Specific goals were to determine the

104 relationship between the compositions of the seed bank and the aboveground vegetation and the

105 effect of shrubs (microhabitat effects) and perennial bunchgrass cover (community phase effects)

106 on the seed bank community composition, seed density, and seed bank species richness.

107

108

109

110

111

\section{Methods}
2.1. Study site 
112 Soil seed bank samples were collected from the Onaqui Sagebrush/Cheatgrass SageSTEP

113 research site in Tooele County, Utah, USA, about $40 \mathrm{~km}$ south of Tooele, UT (40¹1'53"N

$\left.114112^{\circ} 27^{\prime} 51^{\prime \prime} \mathrm{W}\right)$. The Onaqui site is located on the eastern toeslope of the Onaqui mountains at an

115 elevation of 1750-1850 meters (McIver et al., 2010). Based on Utah Climate Center data from

116 the Vernon climate station (Latitude: 40.1125, Longitude: -112.435; Elevation: $1671 \mathrm{~m}$; Period:

117 1953-2010), about $11.3 \mathrm{~km}$ south of the study site and in the same valley, mean monthly

118 temperature ranges from $-3.1 \mathrm{C}$ in January to $22.0 \mathrm{C}$ in July, while mean monthly precipitation

119 ranges from $17.5 \mathrm{~mm}$ in December to $29.5 \mathrm{~mm}$ in May, yielding a mean annual precipitation of

$120264.4 \mathrm{~mm}$. Snow can occur in all months except July and August with a peak in January (Utah

121 Climate Center, 2012). Onaqui has fine-loamy soils (McIver et al., 2010).

122 Characteristic vegetation of this site includes Wyoming big sagebrush (Artemisia

123 tridentata ssp. wyomingensis), shadscale saltbush (Atriplex confertifolia), yellow rabbitbrush

124 (Chrysothamnus viscidiflorus), Sandberg bluegrass (Poa secunda), squirreltail (Elymus

125 elymoides), Indian ricegrass (Achnatherum hymenoides), bluebunch wheatgrass

126 (Pseudoroegneria spicata), basin wildrye (Leymus cinereus), and cheatgrass (Bromus tectorum).

127 Seed bank germination assays were conducted at the Utah State University Research

128 Greenhouse Facility in Logan, UT.

129

\subsection{Experimental design}

131 This study presents the results of baseline sampling of the seed bank of the Onaqui

132 sagebrush-cheatgrass site of the SageSTEP network (McIver et al., 2010). The sagebrush-

133 cheatgrass portion of SageSTEP is a large experimental study addressing the effects of

134 restoration treatments (control, prescribed burn, mow, tebuthiuron herbicide, and imazapic

$135\left[\right.$ Plateau $\left.^{\circledR}\right]$ pre-emergent herbicide) on sagebrush ecosystems. Burn, mow, and tebuthiuron 
136 treatments were designed to reduce shrub cover, while imazapic is used to reduce the emergence

137 and establishment of exotic annuals. All results presented in this paper are pretreatment and thus

138 do not address the effects of treatments; nonetheless, we describe the experimental design and

139 refer to sampled plots and subplots by their treatment names because treatment effects will be

140 addressed in a subsequent paper. In the present study, the treatment plots should be viewed

141 simply as replicate plots of untreated sagebrush ecosystems.

142 Control, prescribed burn, mow, and tebuthiuron treatments were applied at the whole plot

143 level (75 acres; 30.4 ha), while imazapic was applied at the subplot level (0.1 ha) as a split-plot

144 factor in all whole plots. In the seed bank studies at Onaqui the mow treatment was excluded,

145 leaving three plot-level treatments and one subplot-level treatment.

146 In each sampled plot, subplots with two levels of perennial bunchgrass cover were

147 sampled. Community phases were chosen by dividing the cover of perennial bunchgrasses into 3

148 ranges. Subplots with greater than 19 percent perennial bunchgrass cover were considered phase

1491 communities, those with 10-19 percent bunchgrass cover were considered phase 2 , and those

150 with less than 10 percent perennial bunchgrass cover were considered phase 3 communities. In

151 the present study only phase 1 and 3 communities were sampled in order to examine the effects

152 of high and low native bunchgrass covers on seed banks. Four phase 1 subplots and four phase 3

153 subplots that did not receive Plateau ${ }^{\circledR}$ were sampled in the control $(\mathrm{CO})$, prescribed burn (FI),

154 and tebuthiuron (TE) plots, and four phase 1 subplots and four phase 3 subplots that did receive

155 Plateau ${ }^{\circledR}$ also were sampled in the control plot for a total of 32 subplots. Although the set of the

156 control subplots that received Plateau are not from a true plot, we refer to these subplots as the

157 control-Plateau $^{\circledR}$ plot $(\mathrm{CP})$ for convenience.

158

159 2.3. Seed bank sampling 
Soil seed bank samples were collected 14-17 and 22-24 August 2006. Within each 0.1-ha

$162(30 \times 33 \mathrm{~m})$ subplot, four $28-\mathrm{m}$ transects were laid out so as to not interfere with vegetation

163 surveys. Transects ran north-south and were located at 3, 10, 20, and 27 meters from the

164 northwest corner of the subplot. A composite sample consisting of 5 subsamples from within a

$16525 \times 25-\mathrm{cm}$ frame was collected every 3 meters along each of the 4 transects for a total of 10

166 composite samples per transect and 40 per subplot. Collecting many small samples has been

167 shown to increase the precision of estimates of seed numbers in the soil (Bigwood and Inouye,

168 1988). If necessary, sampling locations were shifted slightly in order to assure that all 5

169 subsamples were from the same microhabitat (see below). Subsamples measured $6.1 \mathrm{~cm}$ in

170 diameter and were taken to a depth of $4 \mathrm{~cm}$ with PVC couplings. Litter and soil layers were

171 collected together. Microhabitat (shrub interspace or beneath shrub) was recorded for each

172 composite sample collected.

173

\subsection{Vegetation surveys}

175 Aboveground vegetation surveys were conducted on transects located at 2, 7, 15, 23, and

17628 meters from the northwest corner of each subplot. The line-point intercept method was used

177 to measure the cover of each species present along each transect (Herrick et al., 2005). Species

178 intercepted by the pin were recorded every half meter totaling 60 points per transect and 300

179 points per subplot. Subplots were then surveyed to account for any additional species that were

180 not encountered on transects and were assigned a dominance class. Class 1 represents rare

181 species (1-2 plants per subplot); class 2 represents sparse species $(<5 \%$ cover); class 3 represents

182 common species ( $5-25 \%$ cover); class 4 represents co-dominant species ( $25-50 \%$ cover), and

183 class 5 represents dominant species ( $>50 \%$ cover). Of the additional species found in the subplot 
184 survey, none had a higher dominance than 3. Dominance classes were then converted to relative

185 abundance for analysis. Class 1 was converted to 0.0033 (equivalent to a species being hit once

186 during line-point intercept). Class 2 was converted to 0.04 (4\% cover), and class 3 was

187 converted to 0.15 (15\% cover). Vegetation surveys were conducted in summer 2006.

188 Nomenclature for all plant species followed the USDA NRCS PLANTS Database (2009).

189

190

191

192

193

194

195

196

197

198

199

200

201

202

203

204

205

206

207

208

\subsection{Evaluating the seed bank}

The germinable seed bank was evaluated by direct germination in a greenhouse following cold-moist stratification, which has been shown to be an efficient and reliable method for determining species presence in the germinable seed bank (Gross, 1990). Each composite sample was moistened to field capacity and kept in an unlighted refrigerator at $2^{\circ} \mathrm{C}$. After 60 days of stratification, samples were removed from the refrigerator and spread over a 2-cm layer of sand in planting trays with drainage holes. Planting trays were divided into three 25.4 X 16.9cm compartments, each containing one soil sample. Spread out soil samples had a depth of $\approx 1.3$ $\mathrm{cm}$ and a volume of $\approx 585 \mathrm{~cm}^{3}$. Samples were kept moist, and seedlings were identified, counted, and removed as they emerged. Individuals that were not identified in the seedling stage were transplanted and grown until mature.

Due to the high volume of samples collected, not all seed bank samples were evaluated at the same time. Therefore, depending on the availability of greenhouse space, varying numbers of samples were randomly selected from each treatment combination for each germination assay. Eleven of the 40 samples from each treatment combination were germinated and evaluated for each of the first and second germination assay. Six samples from each treatment combination were germinated and evaluated for the third germination assay, and nine samples were germinated and evaluated for the fourth germination assay. Thus, a total of 37 of the 40 samples 
209 per subplot were germinated. Each germination assay lasted 150 days. Emergence was initially

210 censused for 115 days, at which point emergence was noticeably reduced. Samples were then

211 dried out for 14 days and mixed, after which watering was resumed and emergence was censused

212 for an additional 21 days.

213 The first germination assay ran from mid-January to mid-June 2007. The second

214 germination assay ran from mid-June to mid-November 2007. The third germination assay ran

215 from mid-January to mid-June 2008, and the fourth germination assay ran from mid-June to mid-

216 November 2008. First and third germination assays and second and fourth assays ran during the

217 same time of year so as to control for potential seasonal germination effects that could bias

218 results.

219

220

221

222

223 version 2.6.2 (R Development Core Team, 2008) to compare the seed community to the

224 aboveground community. These two similarity/distance metrics compare two communities in

225 different ways. Sørensen's similarity is based strictly on presence/absence: $C_{s}=2 w /(2 w+A+B)$

226 where $w$ is the total number of species found in both communities, $A$ is the number of species

227 excusive to aboveground, and $B$ is the number of species exclusive to belowground. A $C_{s}$ of 0

228 represents completely dissimilar communities and $C_{s}$ of 1 represents identical communities at the

229 level of presence/absence. In contrast to Sørensen’s similarity index, Bray-Curtis distance

230 incorporates information on relative abundance (or cover). This metric normalizes relative

231 abundance for communities being compared by dividing the absolute differences by the

232 summation: $B C=\sum_{i}^{n}\left|x_{i j}-x_{i k}\right| / \sum_{i}^{n} x_{i j}+x_{i k}$ where $x_{i j}$ is the relative abundance of species $i$ in 
233 community $j, x_{i k}$ is the relative abundance of species $i$ in community $k$, and $n$ is the total number

234 of species. A $B C$ of 0 represents most similar communities, and a $B C$ of 1 represents most

235 different communities. $C_{s}$ and $B C$ were calculated for the entire site and for each plot using

236 relative cover of the aboveground community and relative abundance of the germinable seed

237 bank community to avoid differences in sampling scales.

238 To further compare the community composition of the germinable seed bank to that of

239 the aboveground vegetation, seed bank composition data were ordinated by non-metric

240 multidimensional scaling (NMDS) with a Bray-Curtis distance measure using the metaMDS

241 function in the Vegan package in R version 2.11.1 (Oksanen et al., 2008; R Development Core

242 Team, 2008). Specifically, seed bank composition was compared to the aboveground vegetation

243 structure by assigning one of seven functional groups to all species present aboveground: annual

244 forbs, annual grasses, perennial forbs, perennial grasses, Poa secunda, shrubs, and trees. As with

245 the similarity and distance metrics, relative cover of the aboveground community and relative

246 abundance of the germinable seed bank community were used to avoid differences in sampling

247 scales. Functional groups were based on different morphologies and root systems. Poa secunda

248 was considered a different functional group than perennial grasses because $P$. secunda is a

249 shorter grass that has a shallower root system compared to the other perennial grasses. The

250 relative covers of aboveground functional groups were fitted and plotted onto the seed bank

251 species composition ordination solution using the envfit function in the Vegan package in $\mathrm{R}$

252 version 2.11.1 with $P<0.05$ to determine significance (Oksanen et al., 2008; R Development

253 Core Team, 2008). NMDS on densities of germinable seed bank species was also used to

254 compare beneath shrub (S) and shrub interspace (I) community compositions and to compare

255 phase 1 and phase 3 community compositions. 
To determine the number of dimensions for each NMDS, stress values were assessed.

257 Stress is a measure of how much the distances in the reduced ordination space depart from the 258 distances in the original p-dimensional space. High stress values indicate a possibility that sites 259 are randomly being placed without any relation to the original distances. Therefore, ordinations

260 with the lowest possible stress are desirable; values up to 20 are acceptable and can be 261 interpreted ecologically (Clarke, 1993). Regardless of the number of dimensions chosen, all 262 figures are shown in two dimensions because the third dimension did not seem to alter results 263 upon inspection.

264 A mixed-model factorial ANOVA (analysis of variance) was performed to detect 265 differences in total seed density and species richness (total number of species present) between 266 aboveground microhabitat and community phase using the MIXED procedure in SAS version 2679.1 .3 (SAS Institute, 2003) and $P<0.05$ to determine significance. Microhabitat and community 268 phase were treated as fixed effects, and plot and subplot were random effects. Because seed 269 bank species composition data were sparse and did not meet the assumptions of normality and 270 heteroscedasticity, seed bank species were grouped into functional groups and analyzed to 271 understand how aboveground microhabitat and community phase affect the structure of the seed 272 bank community. The same ANOVA model described above was used to detect seed density 273 differences within each of six functional groups: annual forb, annual grass, perennial forb, 274 perennial grass, Poa secunda, and shrub. One tree species (Tamarix ramosissima) was found in 275 the germinable seed bank but was not analyzed as a functional group due to very low seed 276 densities and only one species present. Species richness was not analyzed within functional 277 group because sample sizes were too low and assumptions of normality and heteroscedasticity 278 were unable to be met. 
Total seed density and species richness across functional groups were log transformed to

280 meet the assumptions of normality and homogeneity of variance. Seed densities within the

281 perennial grass, perennial forb, annual forb, Poa secunda, and shrub functional groups were

282 square root transformed. Seed density within the annual grass functional group was log

283 transformed. For significant main effects, least squared means were compared using Tukey's

284 test. Least squared means and standard errors were back-transformed for figures.

285

286

287

288

289

290

291

292

293

294

295

296

297

298

299

300

301

302

303

304

\section{Results}

\subsection{Relationship between the germinable seed bank and aboveground vegetation}

A total of 47 species germinated from the seed bank, and 43 species were recorded aboveground (Appendix A; Appendix B). The germinable seed bank and aboveground vegetation were moderately different in terms of species presence at the overall site scale according to Sørensen's similarity index $\left(C_{s}=0.447\right)$. Results were similar for all individual plots $\left(\mathrm{CO} C_{s}=0.421 ; \mathrm{FI} C_{s}=0.436 ; \mathrm{TE} C_{s}=0.511 ; \mathrm{CP} C_{s}=0.433\right)$. When relative abundance was incorporated, Bray-Curtis distance showed a similar trend, where the germinable seed bank and aboveground vegetation were moderately dissimilar at the overall site level and the individual plot levels (Site $B C=0.609$; $\mathrm{CO} B C=0.580$; FI $B C=0.587$; $\mathrm{TE} B C=0.627$; $\mathrm{CP} B C=$ 0.638). Sørensen's similarity index concluded that the CO plot had the most dissimilar aboveground-belowground communities while Bray-Curtis distance found that $\mathrm{CP}$ had the highest dissimilarity. According to Sørensen’s similarity index the aboveground-belowground communities were most similar in the TE plot. However, Bray-Curtis distance identified the CO plot as having the most similar aboveground-belowground communities.

The NMDS with two dimensions was an acceptable representation of the original 
germinable seed bank data (stress $=7.18$ ). Four of the seven aboveground structure variables

306 (functional groups) were significantly correlated with the germinable seed bank community, with

307 correlations being highly significant for annual grasses and annual forbs, as expected (Table 1).

308 The two most dominant annual grass species present in the germinable seed bank, Bromus

309 tectorum (brte) and Vulpia octoflora (vuoc), were positively correlated with the cover of the

310 aboveground annual grass functional group (Fig. 1).

311

312

313

314

315

316

317

318

319

320

321

322

323

\subsection{Effects of micohabitat and aboveground community phase on germinable seed bank community, seed densities, and species richness}

\subsubsection{Germinable seed bank community}

The NMDS plot constructed to compare microhabitats with three dimensions was an acceptable solution (stress=19.88). Interspace and beneath shrub communities did not display distinct community compositions as indicated by the lack of separation in the ordination plot between the two microhabitats (Fig. 2).

The NMDS comparing aboveground community phase required three dimensions to achieve an acceptable stress level of 17.38. There was no obvious separation of phase 1 and phase 3 community compositions (Fig. 3).

\subsubsection{Seed density}

ANOVA showed that seed density was not significantly affected by microhabitat, phase, or the microhabitat $\mathrm{x}$ phase interaction (Table 2). Shrub seed density was the only functional group significantly affected by any of the factors (Table 2). Microhabitat had a significant effect on shrub seed density, with more seeds found beneath shrubs $(6.74 \pm 3.12)$ than in interspaces $(3.17 \pm 4.46)$ 
ANOVA showed that species richness of the germinable seed bank was not significantly affected by microhabitat, phase, or the microhabitat x phase interaction (Table 2).

\section{Discussion}

\subsection{Relationship between the germinable seed bank and aboveground vegetation}

Despite findings that desert grassland germinable seed bank communities may

344 correspond to the aboveground vegetation as a result of limited seed dispersal and clustered 345 seeds surrounding parent plants (Shaukat and Siddiqui, 2004), our results from the similarity and 346 distance metrics did not strongly support this expectation. Both Sørensen's similarity index and 347 Bray-Curtis distance indicate that the germinable seed bank and aboveground community 348 compositions were moderately different at the overall site and individual plot levels. At the plot

349 level, Sørensen's similarity index and Bray-Curtis distance give conflicting results as to which

350 plot had the most and least similar aboveground-belowground communities. This is likely due to 351 Sørensen's similarity index giving greater importance to rare species. The germinable seed bank 352 and aboveground vegetation only shared 19 of the total of 71 species encountered in this study.

353 However, for most species present in both the germinable seed bank and aboveground

354 vegetation, relative abundances were similar except that Alyssum desertorum and Ceratocephala 355 testiculata were vastly over-represented in the germinable seed bank relative to the aboveground

356 vegetation while Artemisia tridentata was over-represented in the aboveground vegetation 357 relative to the seed bank (Appendix A; Appendix B).

358 Eriksson and Eriksson (1997) have attributed a lack of correspondence between the 359 germinable seed bank and aboveground vegetation to the fact that the dominant species often 
360 differ between the two communities. A. tridentata was the most dominant species aboveground

361 at the Onaqui site. Young and Evans (1989) found that no A. tridentata seeds germinated from

362 the seed bank when collected before fall when A. tridentata seeds mature. In contrast, in the

363 present study germinable $A$. tridentata seeds were found in seed bank samples collected in

364 August, before seed dispersal, but at low densities. Therefore, A. tridentata was over-

365 represented aboveground, which decreased the similarity between the germinable seed bank and

366 aboveground vegetation. Conversely, A. desertorum and C. testiculata were abundant in the

367 germinable seed bank but had lower cover aboveground. Annual species such as A. desertorum

368 and C. testiculata that produce small abundant seeds generally may be over-represented in the

369 germinable seed bank (Eriksson and Eriksson, 1997). Although many factors potentially

370 contribute to seed traits, in general annuals are expected to invest more resources in seed

371 production and, all else equal, produce smaller seeds relative to perennials (Silvertown and

372 Charlesworth, 2001). Also, being annuals, A. desertorum and C. testiculata can produce large

373 germinable seed banks and use seed banking as a bet hedging germination strategy (Philippi and

374 Seger, 1989; Gutterman, 2002; Mistro et al., 2005). A. desertorum and C. testiculata may be

375 maintaining dormant seeds to spread the risk of germination over time, allowing seeds to wait for

376 more favorable germination conditions which may increase the chance of establishment and

377 survival. Another possibility for the over-representation of A. desertorum and C. testiculata

378 belowground is the simple fact that these plants were not frequently encountered aboveground

379 during data collection using the line-point intercept method due to their relatively small size (the

380 probability of a pin hitting a smaller plant is lower than the probability of hitting a larger plant)

381 and due to primarily actively growing much earlier in the season than when the aboveground

382 sampling occurred. 
In contrast to the similarity and distance metrics, the NMDS suggested that the

384 germinable seed bank and aboveground vegetation were in fact moderately similar. One reason

385 for this disagreement is the organizational level of the aboveground vegetation used in

386 comparisons. For the similarity and distance metrics, relative abundances were compared at the

387 species-level. However, the NMDS compared the relative abundance of each species in the

388 germinable seed bank to the relative abundance of aboveground vegetation functional groups, i.e.

389 aboveground vegetation structure. Therefore, at the species-level the germinable seed bank and

390 aboveground vegetation communities were only moderately similar, but similarities were

391 considerably greater when comparing germinable seed bank species abundances to the

392 aboveground functional groups. There were a number of species that were only present above or

393 belowground (Tables A.1 and A.2) which decreased similarity between the germinable seed bank

394 and aboveground vegetation. However, the differences between each species present in either

395 community were no longer detected when using functional group as the aboveground

396 organizational level of comparison.

397 The germinable seed bank and aboveground vegetation tend to be more similar in annual

398 communities than in perennial communities (Thompson and Grime, 1979; Ungar and Woodell,

399 1993; Milberg, 1995; Bakker et al., 1996; Osem et al., 2006). NMDS results from the present

400 study did show a significant correlation between the annual germinable seed bank and

401 aboveground structure, but also a significant correlation between the perennial germinable seed

402 bank and aboveground structure. The unexpected correspondence between the perennial

403 germinable seed bank species and aboveground vegetation structure could simply be a function

404 of the comparison between species and functional groups. As displayed by the similarity and

405 distance metrics, the similarity between germinable seed bank and aboveground species 
compositions was relatively low. However, comparing germinable seed bank species

407 composition to aboveground structure yielded the opposite result. Although the germinable seed

408 bank and aboveground vegetation were not similar at the species level, the germinable seed bank

409 species composition was similar to the aboveground vegetation functional group categories. For

410 example, both Achnatherum hymenoides and Elymus elymoides were positively correlated with

411 the aboveground perennial grass functional group.

412

\subsection{Aboveground community phase and microhabitat effects}

Shrub was the only functional group whose seed density was significantly affected by

417 microhabitat. The beneath shrub microhabitat contained more shrub seeds than interspaces,

418 which has been observed in other studies (Nelson and Chew, 1977; Guo et al., 1998; Marone et

419 al., 2004). Shrub seed densities tend to be higher under shrub canopies due to seeds falling

420 beneath and adjacent to the parent plant (phase I dispersal; Shaukat and Siddiqui, 2004). Shrubs

421 might have decreased wind velocity, physically trapping seeds beneath shrubs (Bullock and

422 Moy, 2004). Another explanation for higher beneath shrub densities is seeds could have been

423 transported by wind or water from interspaces and trapped in the litter beneath shrubs (phase II

424 dispersal; Chambers and MacMahon, 1994). However, if this was the primary reason we would

425 expect to have higher densities of other seed types beneath shrubs as well.

426 There are few studies investigating the spatial pattern of species richness of seeds in

427 desert shrub communities, but Li (2008) reported species richness was highest $2 \mathrm{~m}$ and $6 \mathrm{~m}$ from

428 shrubs. Results from the present research can neither corroborate nor contradict this finding.

429 Species richness was not significantly affected by any of the factors of interest.

430 The invasive grass Bromus tectorum was the most dominant annual grass on site. 
431 However, annual grass seed density was not affected by aboveground community phase,

432 microhabitat, or the community phase $\mathrm{x}$ microhabitat interaction. Although we did not directly

433 examine the effects of Bromus tectorum on the seed bank, the invasion of Bromus tectorum can

434 create shifts to greater annual seed abundance (Young and Evans, 1975; Humphrey and Schupp,

435 2001) which can in turn affect the aboveground vegetation. Regardless of the differences in

436 perennial bunchgrass cover aboveground (community phase), annual grass seed density was not

437 affected-Bromus tectorum seed densities were relatively high as was aboveground cover

438 (Appendix A; Appendix B). Even if an invader can be eradicted aboveground, it may be

439 impossible to restore the vegetation community to the composition of an uninvaded community

440 (Vilà and Gimeno, 2007) due to invasive species persisting in the seed bank. Total seed density

441 and species richness, and seed density and species richness for all other functional groups

442 individually, were not significantly affected by aboveground community phase or microhabitat.

443 Seed banks of semiarid deserts can vary extensively spatially (Marone et al., 2004; Coffin and

444 Lauenroth, 1989) which may make it difficult to detect strong effects of these factors on seed

445 density and species richness.

$446 \quad$ In addition to seed density and species richness, the germinable seed bank species

447 composition was not strongly affected by community phase or microhabitat, or at least NMDS

448 did not detect such effects. Due to variability in seed dispersal patterns among species, distinct

449 germinable seed bank communities as a function of microhabitat and aboveground community

450 phase may not exist.

451 Prior to our research, the relationship between the seed bank and aboveground vegetation

452 had not yet been examined in cold desert plant communities. Our study found that seed

453 densities, species richness, and the germinable seed bank community composition were not 
454 affected by aboveground community phase or, with the exception of shrub functional group seed 455 densities, microhabitat. Species compositions were moderately dissimilar when the germinable 456 seed bank and aboveground vegetation were compared at the species level but were moderately 457 similar when the germinable seed bank was compared to the aboveground vegetation functional 458 groups. These findings provide new insight into seed banks of cold deserts and their potential to 459 influence the aboveground vegetation.

\section{Role of the funding sources}

462 None of the funding sources (see below) played any role in study design; in the 463 collection, analysis, and interpretation of data; in the writing of the report; or in the decision to 464 submit the paper for publication.

\section{Acknowledgements}

Thanks to J. Burnham, D. Scherpenisse, C. Morris, C. Addy, D. Zamecnik, and B.

468 Fowers for field and greenhouse assistance. Also thanks to S. Durham for her statistical advice 469 and L. Shultz, M. Barkworth, and N. Holmgren for assistance with plant identification. We also 470 greatly appreciate P. Adler and T. Evans for their support and guidance. Funding for the 471 research was provided by the Joint Fire Science Program (JFSP Grant \#05-S-08), the Utah 472 Agricultural Experiment Station (UAES), and the Utah State University Ecology Center. This is 473 approved as UAES journal paper number 8317 and as contribution number 63 of the Sagebrush 474 Steppe Treatment Evaluation Project (SageSTEP).

\section{References}


composition along a gradient from dry alvar grassland to Juniperus shrubland. Journal of Vegetation Science 7, 165-176.

Bigwood, D.W., Inouye, D.W., 1988. Spatial pattern analysis of seed banks: an improved method and optimized sampling. Ecology 69, 497-507.

\section{4}

Bullock, J. M., Moy, I.L., 2004. Plants as seed traps: inter-specific interference with dispersal.

485

486 Acta Oecologica 25, 35-41.

Chambers, J.C., MacMahon, J.A., 1994. A day in the life of a seed: movements and fates of seeds and their implications for natural and managed systems. Annual Review of Ecology and Systematics 25, 263-292.

Clarke, K.R., 1993. Non-parametric multivariate analyses of changes in community structure. Australian Journal of Ecology 18, 117-143.

Coffin, D.P., Lauenroth, W.K., 1989. Spatial and temporal variation in the seed bank of a semiarid grassland. American Journal of Botany 76, 53-58.

Eriksson, Å., Eriksson, O., 1997. Seedling recruitment in semi-natural pastures: the effects of disturbance, seed size, phenology and seed bank. Nordic Journal of Botany 17, 469-482.

Gross, K.L., 1990. A comparison of methods for estimating seed numbers in the soil. The Journal of Ecology 78, 1079-1093.

Guo, Q., Rundel, P.W., Goodall, D.W., 1998. Horizontal and vertical distribution of desert seed banks: patterns, causes, and implications. Journal of Arid Environments 38, 465-478.

Guo, Q., Rundel, P.W., Goodall, D.W., 1999. Structure of desert seed banks: comparisons across four North American desert sites. Journal of Arid Environments 42, 1-14.

Gutterman, Y. 2002. Survival strategies of annual desert plants. Adaptations of desert organisms. Springer-Verlag, Berlin, Heidelberg, Germany. 
Hassan, M.A., West, N.E., 1986. Dynamics of soil seeds pools in burned and unburned sagebrush semi-deserts. Ecology 67, 269-272.

Henderson, C.B., Petersen, K.E., Redak, R.A., 1988. Spatial and temporal patterns in the seed bank and vegetation of a desert grassland community. The Journal of Ecology 76, 717728.

Herrick, J.E., Van Zee, J.W., Havstad, K.M., Burkett, L.M., Whitford, W.G., 2005. Monitoring Manual for Grassland, Shrubland and Savanna Ecosystems. USDA-ARS Jornada Experimental Range. The University of Arizona Press, Tucson, Arizona, USA.

Hopfensperger, K.N., 2007. A review of similarity between seed bank and standing vegetation across ecosystems. Oikos 116, 1438-1448.

Humphrey, D.L., Schupp, E.W., 2001. Seed banks of Bromus tectorum-dominated communities in the Great Basin. Western North American Naturalist 61, 85-92.

Jurado, E., Flores, J., 2005. Is seed dormancy under environmental control or bound to plant traits? Journal of Vegetation Science 16, 559-564.

Kalamees, R., Zobel, M., 1997. The seed bank in an estonian calcareous grassland: comparison of different successional stages. Folia Geobotanica 32, 1-14.

Kemp, P.R., 1989. Seed banks and vegetation processes in deserts. In: Leck, M.A., Parker V.T., Simpson, R.L. (Eds.), Ecology of Soil Seed Banks. Academic Press, New York, pp. 257282.

Kigel, J., 1995. Seed germination in arid and semiarid regions. In: Kigel, J., Galili, G. (Eds.), Seed Development and Germination. Marcel Dekker, New York, pp. 645-699.

Koniak, S., Everett, R.L., 1982. Seed reserves in soils of successional stages of pinyon woodlands. American Midland Naturalist 108, 295-303. 
Li, F.R., 2008. Presence of shrubs influences the spatial pattern of soil seed banks in desert herbaceous vegetation. Journal of Vegetation Science 19, 537-548.

Li, F.R., Zhao, W.Z., Kang, L.F., Liu, J.L., Huang, Z.G., Wang, Q. 2009. Seed distribution of four co-occurring grasses around Artemisia halodendron shrubs in a sandy habitat. Acta Oecologica 35, 444-451.

Marone, L., Cueto, V.R., Milesi, F.A., Lopez de Casenave, J., 2004. Soil seed bank composition over desert microhabitats: patterns and plausible mechanisms. Canadian Journal of Botany 82, 1809-1816.

McIver, J.D., Brunson, M., Bunting, S.C., Chambers, J., Devoe, N., Doescher, P., Grace, J., Johnson, D., Knick, S., Miller, R., Pellant, M., Pierson, F., Pyke, D., Rollins, K., Roundy, B., Schupp, E., Tausch, R., Turner, D. 2010. The Sagebrush Steppe Treatment Evaluation Project (SageSTEP): a test of state-and-transition theory. Gen. Tech. Rep. RMRS-GTR237.U.S. Department of Agriculture, Forest Service, Rocky Mountain Research Station, Fort Collins, CO, 16 pp.

Milberg, P., 1995. Soil seed bank after eighteen years of succession from grassland to forest. Oikos 72, 3-13.

Mistro, D.C., Rodrigues, L.A.D., Schmid, A.B., 2005. A mathematical model for dispersal of an annual plant population with a seed bank. Ecological Modelling 188, 52-61.

Nelson, J.F., Chew, R.M., 1977. Factors affecting seed reserves in the soil of a Mojave desert ecosystem, Rock Valley, Nye County, Nevada. American Midland Naturalist 97, 300320.

O'Connor, T.G., 1991. Local extinction in perennial grasslands: a life-history approach. The American Naturalist 137, 753-773. 
Oksanen, J., Kindt, R., Legendre, P., O’Hara, B., Simpson, G.L., Stevens, M.H.H. 2008. Vegan: Community Ecology Package. R package version 1.13-1. Available from: http://vegan.rforge.r-project.org/.

Osem, Y., Perevolotsky, A., Kigel, J., 2006. Similarity between seed bank and vegetation in a semi-arid annual plant community: the role of productivity and grazing. Journal of

Philippi, T., Seger, J., 1989. Hedging one's evolutionary bets, revisited. Trends in Ecology \& Vegetation Science 17, 29-36. Evolution 4, 41-44.

R Development Core Team, 2010. R: A language and environment for statistical computing. R Foundation for Statistical Computing, Vienna, Austria.

SAS Institute. 2003. SAS System for Microsoft Windows. SAS Institute, Inc., Cary, North Carolina, USA.

Shaukat, S.S., Siddiqui, I.A., 2004. Spatial pattern analysis of seeds of an arable soil seed bank

Silvertown, J. and D. Charlesworth. 2001. Introduction to Plant Population Biology. Fourth and its relationship with above-ground vegetation in an arid region. Journal of Arid Environments 57, 311-327.

St. Clair, S.B., Sudderth, E.A., Castanha, C., Torn, M.S., Ackerly, D.D. 2009. Plant responsiveness to variation in precipitation and nitrogen is consistent across the compositional diversity of a California annual grassland. Journal of Vegetation Science $20,860-870$.

Thompson, K., Grime, J.P., 1979. Seasonal variation in the seed banks of herbaceous species in 
ten contrasting habitats. The Journal of Ecology 67, 893-921.

572 Ungar, I.A., Woodell, S.R.J., 1993. The relationship between the seed bank and species

573 composition of plant communities in two British salt marshes. Journal of Vegetation

$574 \quad$ Science 4, 531-536.

575 USDA, NRCS, 2009. The PLANTS Database. National Plant Data Center, Baton Rouge,

576 Louisiana, USA. Available from: http://plants.usda.gov.

577 Utah Climate Center, 2012. Utah State University. Logan, Utah, USA. Available from:

578 http://climate.usurf.usu.edu/reports/monthly_data_summary.php?stn=429133\&unit=SI

$579 \quad$ Accessed 16 December 2011.

580 Vilà, M., Gimeno, I., 2007. Does invasion by an alien plant species affect the soil seed bank?

581 Journal of Vegetation Science 18, 423-430.

582 Young, J.A., Evans, R.A., 1975. Germinability of seed reserves in a big sagebrush community.

$583 \quad$ Weed Science 23, 358-364.

584 Young, J.A., Evans, R.A., 1989. Dispersal and germination of big sagebrush (Artemisia

585 tridentata) seeds. Weed Science 37, 201-206. 